\title{
Городской перекресток и литература (архитектура в литературе или литература в архитектуре?)
}

\author{
А.В.Анисимов, НИИТИАГ, МГСУ, Москва
}

Автор посвятил статью тихим кварталам в самом центре Петербурга в излучине канала Грибоедова между Казанской улицей и Кокушкиным мостом. Эти кварталы и переулки многократно описаны в произведениях Ф.М. Достоевского, связаны с жизнью знаменитых писателей и поэтов: Гоголя, Лермонтова, Пушкина, Мицкевича, Успенского и др. и вошли в русскую классическую литературу и жизнь её создателей. В то же время градостроительная структура этого места с короткими идеально прямыми улицами - очень характерна для спокойной части центра северной имперской столицы России. Центром избранного места стал перекрёсток Столярного переулка и Казначейской улицы, на которой в трёх домах жил Фёдор Михайлович Достоевский, а тридцатью годами ранее вблизи от него - Николай Васильевич Гоголь. Здесь же, на углу Казначейской улицы и канала родился и жил пятнадцать лет автор предлагаемой статьи. Великая литература - охранная грамота этого тихого оазиса старых домов и гранитных берегов канала.

Ключевые слова: перекрёсток, улица, переулок, канал, набережная, мост, градостроительная структура, дом, квартира, литература, писатель, поэт.

Городской перекрёсток современной жизни - опасное место. Транспорт, мчащийся в разных направлениях, своевольные пешеходы, безумные мотоциклисты, велосипедисты и не всегда исправно работающие светофоры создают нервную обстановку, взвинчивающую накал и без того напряжённого существования человека в сегодняшнем мире. Теперь научились превращать эти «милые» перекрёстки в многоуровневые транспортные развязки, аннексирующие городскую территорию. Кроме этих бойких перекрёстков в исторических городах (даже в самых центральных районах!) ещё существуют малые тихие пересечения спокойных улиц и переулков. Их малые перекрёстки - пока ещё наследие пешеходов. Это пауза, отдых для жителей миллионных городов. Думая о них, я невольно вспоминаю тихий перекрёсток своей ранней молодости в самом центре тогда уже трёхмиллионного города Ленинграда первых послевоенных лет. Он до сих пор сохранил свои очертания, но спокойствие из него медленно, но неотвратимо ускользает.

1940-е - 1950-е годы. Геометрический крест, который в излучине канала Грибоедова недалеко от петербургской Сенной площади образовали Казначейская улица (в прошлом Малая Мещанская) и Столярный переулок (рис. 1). Bсе горизонтальные улицы строго параллельны друг другу. А их всех пересекает под прямым углом от Казанской улицы до
Кокушкина моста Столярный переулок - чёткая несгибаемая ось райончика этих Мещанских улиц (рис. 2). В эту тихую заводь в те годы почти не заезжали машины. Появление грузовика на Казначейской было целым событием в моём детстве. В этих домах, как мне говорили, тогда была всего

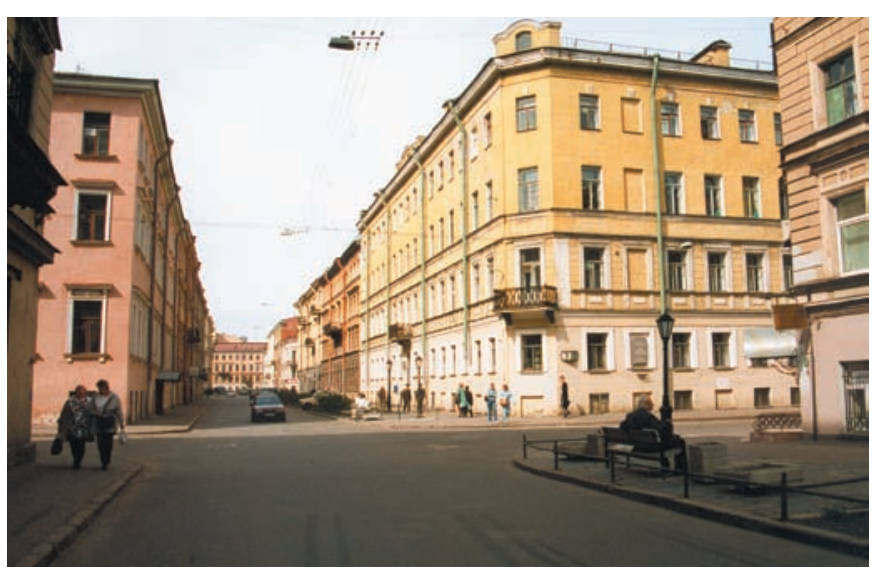

Рис. 1. Пересечение Столярного переулка и Казначейской улицы: знаменитый перекрёсток Достоевского и Раскольникова. Слева - дом 9 по Казначейской. Здесь Федор Михайлович прожил не более 2-х месяцев, справа - дом №7. В нём писатель закончил «Преступление и наказание» и написал «Игрока». Балкон на углу - в его квартире. Фото из открытых источников интернета

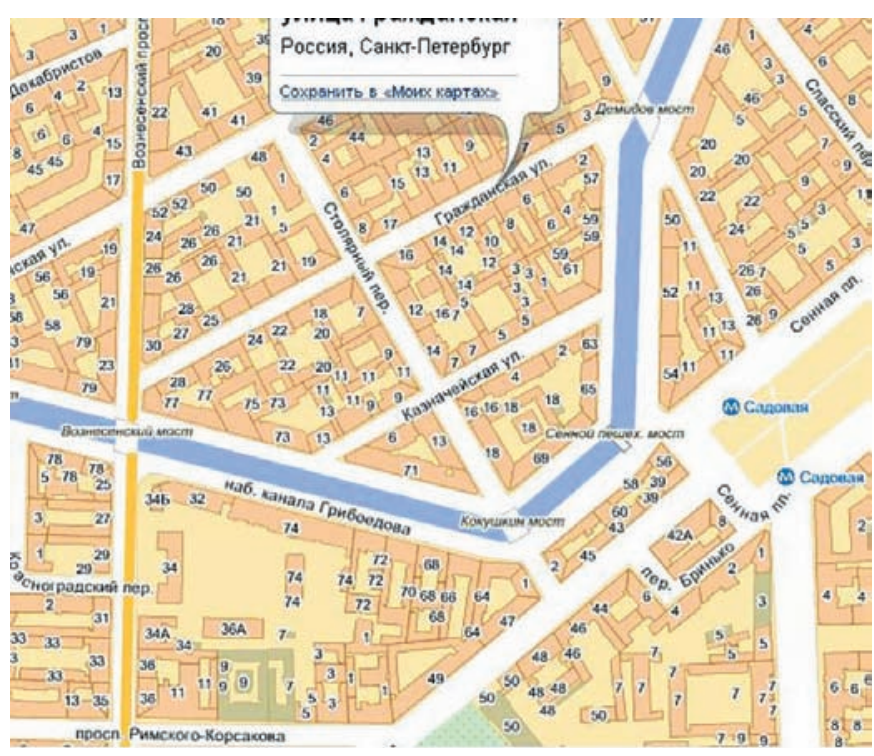

Puс. 2. Карта С.-Петербурга. Фрагмент с изгибом канала, в который упираются обеими концами Казначейская и Гражданская улицы-места действия романа Достоевского, его съёмных квартир и моего жилища с 1935 по 1950 год (источник: Яндекс карты) 
одна частная машина - в доме № 5 у академической семьи Каплянских, вместе с детьми которых я учился в школе № 253 на углу канала и Демидова переулка.

Но этот перекрёсток, я думаю, навсегда вошёл в русскую литературу вместе с его окружением и Екатерининским каналом, где были ещё четыре таких же тихих мирных пересечения. Здесь скромная неяркая архитектура (нестоличная, но очень петербургская) вошла в тесный контакт с великой русской литературой и обессмертилась за её счёт. Застройка этих мест фактически сохранилась со времён Фёдора Михайловича Достоевского (1821-1881), который жил в доме № 1 по Казначейской улице на углу с набережной «канавы» [1]. Только отдельные дома были надстроены на один-два этажа без деформации установленной

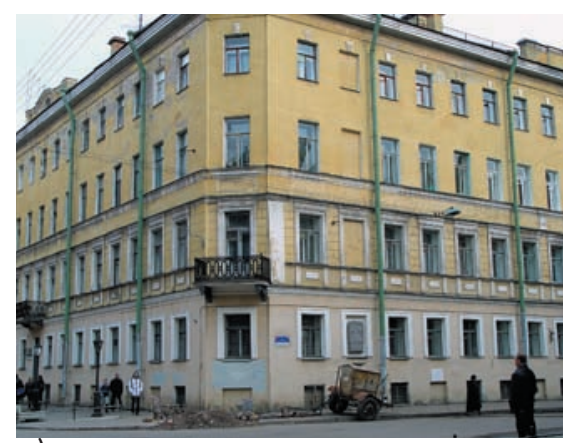

a)

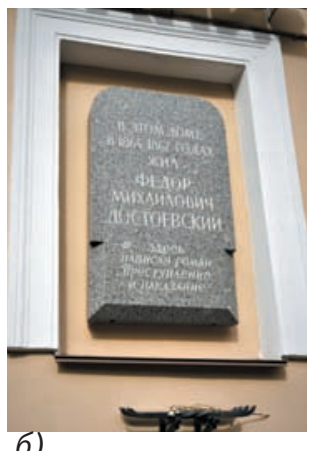

б)

Рис. 3 Казначейская улица, 7. Фото А.В. Анисимова: а) доходный дом И.М. Алонкина. Здесь Достоевский заканчивал «Преступление и наказание», написал роман «Игрок» и решил жениться на своей стенографистке А.Г. Снитковой; б) мемориальная доска, посвящённая великому жителю. Фото из открытых источников интернета

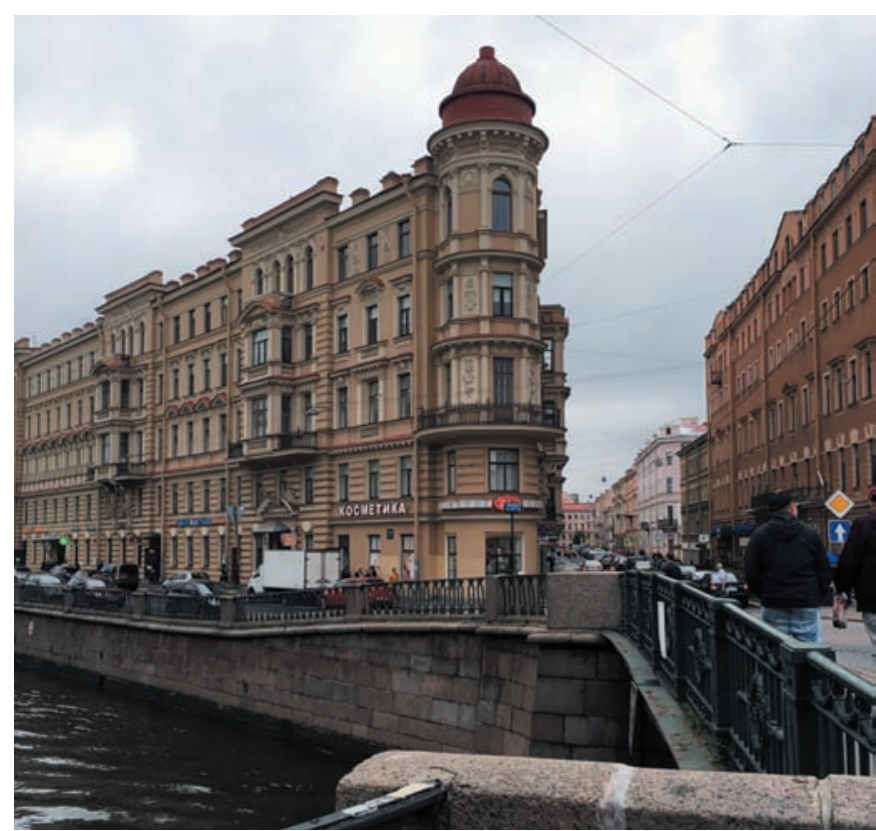

Рис. 4. Вид со стороны Кокушкина моста (на переднем плане) в сторону Столярного переулка. Слева-доходный дом В.А. РотьковаРожнова. Архитектор П.Ю. Сюзор. 1886-1888 годы; справа - дом, где жил Н.В. Гоголь. Фото из открытых источников интернета планировки улиц. Спустя восемьдесят лет (1940-е годы) я оказался его ближайшим соседом в доме № 2 на той же улице и тоже на втором этаже, где родился и прожил пятнадцать лет. Это и даёт мне право вспомнить о тихом перекрёстке моего детства, который ещё сохраняет свои отдельные черты.

Прямо на углу со Столярным переулком, на Казначейской в доме № 7 (рис. 3) на втором этаже в 1864-1867 годах Достоевский заканчивал своё «Преступление и наказание» и диктовал стенографистке А.Г. Снитковой (своей будущей жене) роман «Игрок» [2], который писал на кабальных условиях с издательством. После великого писателя этот дом был надстроен на два этажа и приобрёл свой современный вид. На нём появилась мемориальная доска, посвящённая великому жителю. По диагонали от него на том же пересечении Столярного переулка с моей Казначейской встал уже после Фёдора Михайловича солидный треугольный в плане дом - предвестник модерна (рис. 4). Его построил в 1886-1888 годы архитектор граф П.Ю. Сюзор для богатого заказчика Владимира Александровича Ратькова-Рожнова (1834-1912) [3], владельца почти двадцати доходных домов в столице. Это был известный в столице общественный деятель, предприниматель, представитель династии петербургских промышленников и домовладельцев, действительный тайный советник (1898). По окончании юридического факультета Санкт-Петербургского университета (1857) он служил в Сенате и Петербургском окружном суде, с 1876-го - гласный Городской думы, с 1880-го - гласный губернского земского собрания, в 1893-1898 годах - петербургский городской голова. С 1904 - сенатор. Сюзор построил для него три больших жилых комплекса в центре города. На указанном перекрёстке как раз и стоял один из них, украшая и канал, и Казначейскую, и Столярный переулок.

Раньше на этот переулок выходил известный трактир купца Свиридова «Der Spieler» («Игрок»), который был встроен в этот новый дом Сюзора. Трактир этот посещал Ф.М. Достоевский, бывал здесь и И.С. Тургенев. Не в честь ли романа Достоевского «Игрок» так назвали его немцы?..

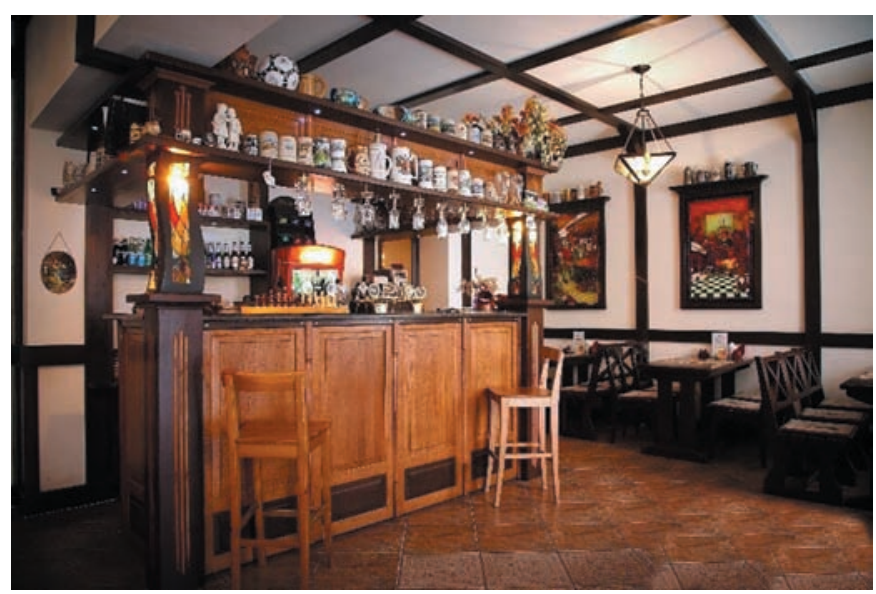

Puc. 5. Казначейская улица, 6. Ресторан «Der Spieler» («Игрок»). Фрагмент воссозданных интерьеров в наше время (источник: https://account.spb.ru/upload/8795/photo.jpg) 
«Немецкий повар переселенец Карл Эрнстман воссоздал меню и бюргерскую атмосферу. Здесь шла игра в шахматы, шашки и карты под скрипичное и аккордеонное исполнение русских и немецких народных песен. Под горячие блюда подавалась за счёт трактира первая рюмка водки. Из очередной поездки по Германии Достоевский привёз и подарил трактиру немецкую фисгармонь “Фортуна" с большой коллекцией пластин. В восстановленном заведении воссозданы интерьеры (рис. 5). Сохранена фисгармонь с прежней коллекцией пластин» [4].

Известный своей чистотой и хорошей кухней трактир привлекал писателей и художников.

С перекрёстка хорошо видно трёхэтажное здание по улице Казначейская, № 11, построенное в 1896-1897 годах для Губернского казначейства. В честь него через 16 лет после смерти Достоевского и была переименована в Казначейскую улица Малая Мещанская улица. До этого здесь стояло низкое камен- ное здание Казённой палаты, в которой три года (1783-1786) служил ещё один известный литератор - баснописец Иван Андреевич Крылов, будучи на тот момент юным канцеляристом.

Особый петербургский колорит окружающей застройки вошёл в незабываемые тексты Федора Михайловича. На углу с «канавой» (каналом Грибоедова, Екатерининским каналом) за казённой палатой в его время стоял «трёхэтажный, старый и зелёного цвета» дом с комнатами портного Капернаумова, в который он поселил Сонечку Мармеладову (рис. 6). Именно здесь в её комнате Раскольников вдруг «весь быстро наклонился и, припав к полу, поцеловал её ногу» сказав знаменитое: «Я не тебе поклонился, я всему страданию человеческому поклонился...» [5]. Как ни странно, но именно таким - грязно-зелёного цвета - запомнился и мне из 1940-х годов послеблокадного Ленинграда этот дом № 13 по_Казначейской улице. Я его видел точно таким - с галереей во
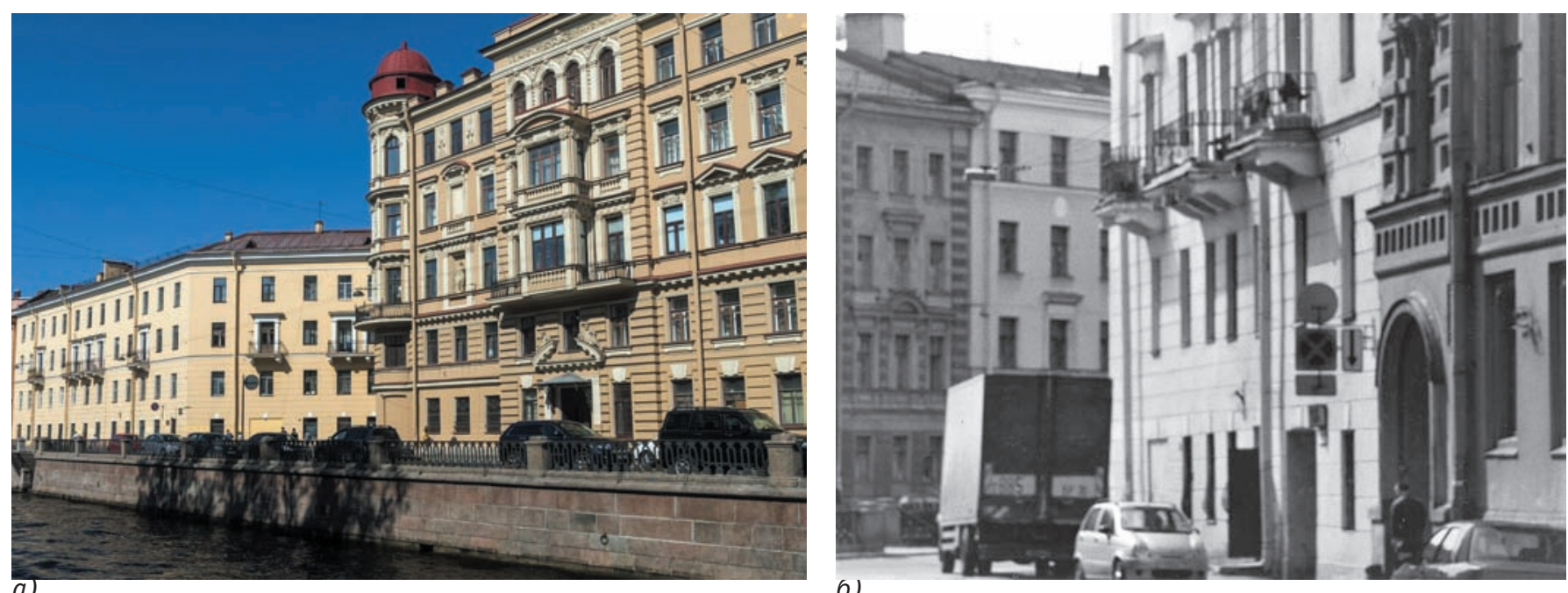

6)

Рис. 6. Набережная канала Грибоедова (бывш. Екатеринский канал), 71-73. Фото А.В. Анисимова: а) сюда (левое здание, дом № 73) Ф.М. Достоевский поселил Сонечку Мармеладову. В 1970-х годах в доме надстроен 4-ый этаж; справа (дом № 71) - доходный дом В.А. Ратькова Рожнова. Построен архитектором П.Ю. Сюзором после смерти Ф.М. Достоевского; б) дом, где жила Соня Мармеладова. Фрагмент. С правого края маленький фрагмент Казначейства

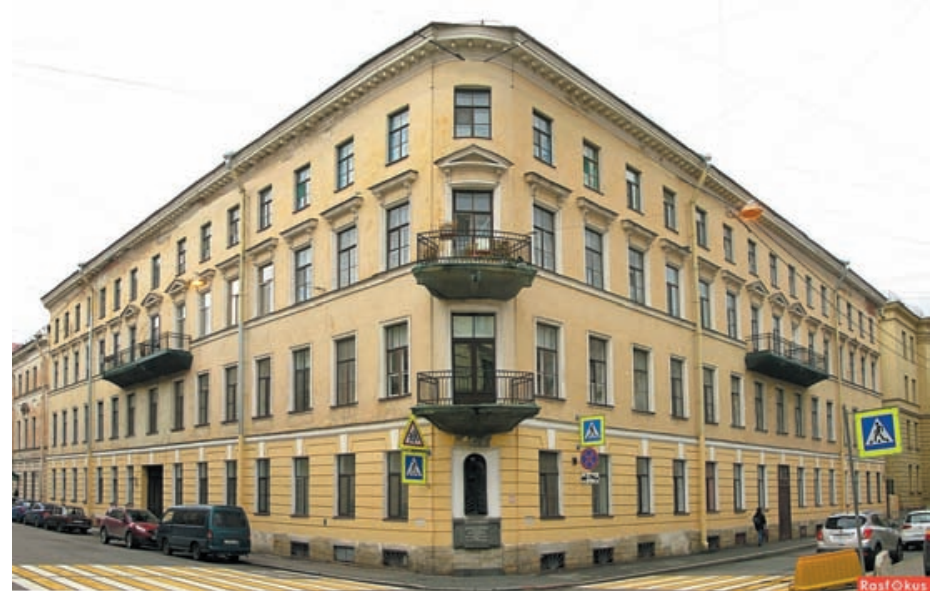

a)

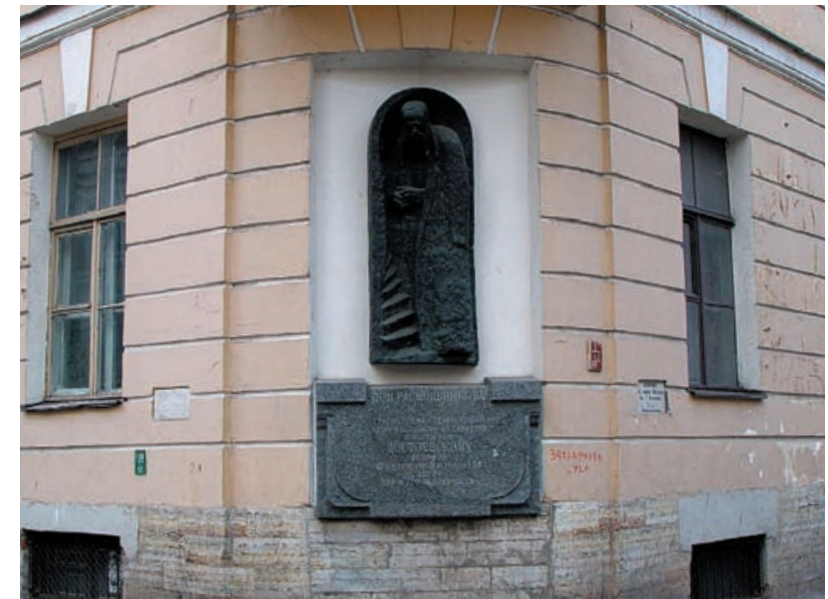

б)

Рис. 7. Гражданская улица, 19. Вправо уходит Столярный переулок. Дом, где жил Родион Раскольников. Фото А. В. Анисимова: а) общий вид; б) фрагмент фасада с мемориальной доской 
внутреннем дворе, как его описывал Достоевский. Позже его надстроили на один этаж, отремонтировали и перекрасили в слишком приличный жёлтый цвет. Дом конечно потерял сразу весь колорит петербургской достоевщины.

Если с этого же перекрёстка посмотреть на север вдоль Столярного переулка, то на следующем таком же, но уже менее тихом перекрёстке с Гражданской улицей, можно увидеть дом (Гражданская улица, 19), на чердаке которого Фёдор Михайлович поселил своего главного героя Родиона Романовича Раскольникова (рис. 7). На его углу в 1999 году был установлен горельеф, выполненный в граните и бронзе. Надпись на плите: «Дом Раскольникова. Трагические судьбы людей этой местности Петербурга послужили Достоевскому основой его страстной проповеди добра для всего человечества».

На другой стороне Столярного переулка в доме Кавоса (№ 6) в 1876-1877 и 1879-1880 годах жил беллетрист-народник Глеб Иванович Успенский (1843-1902). В том же доме и в те же годы жил учёный, путешественник и военный раз-

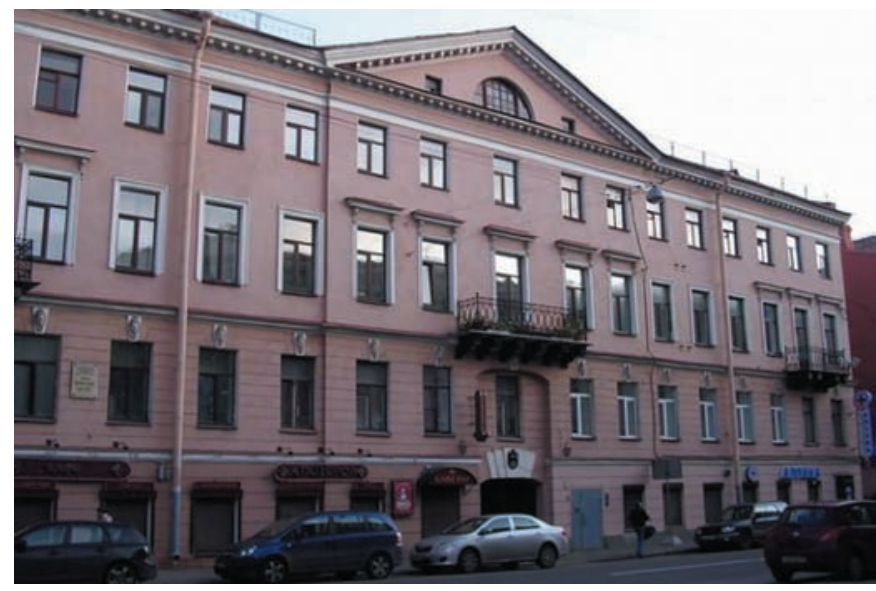

Рис. 8. Казанская улица, 39. Дом мастера И. Иохима. Здесь на четвёртом этаже в 1829 году Н.В. Гоголь снимал квартиру окнами во двор. Фото из открытых источников интернета

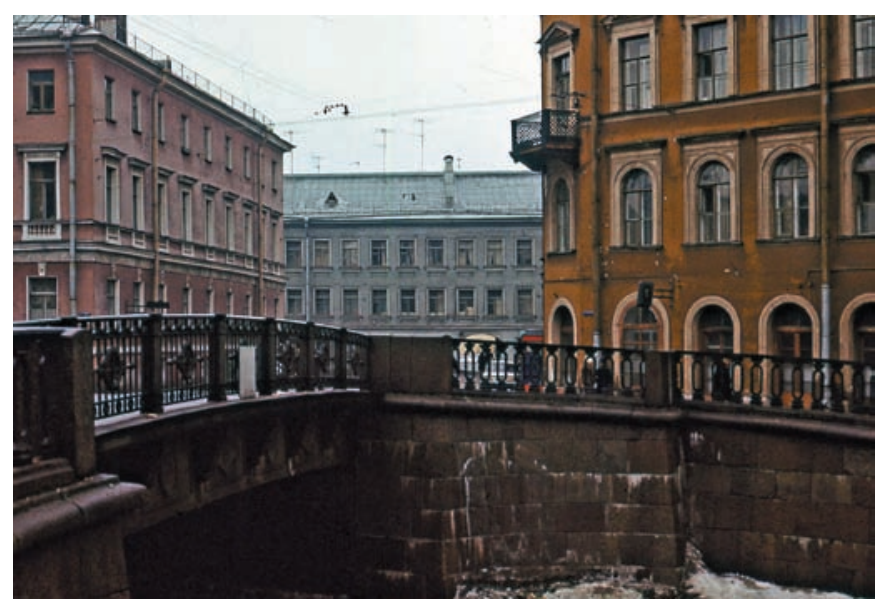

Pис. 9. Вид в сторону Садовой улицы от Кокушкина моста. Фото из открытых источников интернета ведчик генерал-майор Николай Михайлович Пржевальский (1839-1888) - почётный член Петербургской Академии наук, почётный гражданин С.-Петербурга. На доме установлена мемориальная доска. Не случайно в течение почти полувека (с 10 июля 1950 года по 13 января 1998 года) переулок назывался улицей Пржевальского.

Это был собственный дом архитектора Ц.А. Кавоса, сына знаменитого Альберто Катариновича Кавоса - автора Мариинского театра. Доходный дом построен в 1850 году архитектором Я.И. Реймерсом, а в 1871-ом был перестроен владельцем архитектором Цезарем Альбертовичем Кавосом. Теперь это общежитие № 3 Санкт-Петербургского государственного университета путей сообщения.

Далее Столярный упирается в застройку Казанской улицы. Это тоже скромный Т-образный перекрёсток, оживленный в первой половине XX века бренчащим старым трамваем. Там с нашего перекрёстка виден красноватый дом с небольшим фронтоном (в 1940-х годах, я чётко помню, он был ярко-бордового цвета), в котором с апреля 1828-го по май 1829-го жил известный польский поэт Адам Мицкевич и на четвёртом этаже которого в 1829 году Н.В. Гоголь снимал квартиру окнами во двор (рис. 8). Там пока ещё никому не известный Николай Васильевич Яновский-Гоголь делает первые наброски будущих «Вечеров на хуторе близ Диканьки» и изо всех сил пытается подружиться с Пушкиным.

Этот дом принадлежал известному всему Петербургу каретному мастеру И. Иохиму, который построил его для себя, чтобы перебраться в 1813 году из своей мастерской на Литейном проспекте. Приятелем Карла Иохима, сына владельца дома - вольного слушателя Академии художеств -был Тарас Шевченко, о чём он упоминает в своей автобиографической повести «Художник». Это ещё один литератор тихих перекрёстков.

0 Столярном переулке в газете «Петербургский листок» в 1865 году сообщалось следующее: «В Столярном переулке находится шестнадцать домов. В этих шестнадцати домах помещается восемнадцать питейных заведений...»

Противоположный конец Столярного переулка направлен к Садовой улице и Юсупову саду. Но не доходя до них, он превращается в ещё один перекрёсток в виде известного Кокушкина моста (рис. 9). Именно с этого места начинается повествование «Преступления и Наказания»: «...один молодой человек вышел из своей каморки, которую он снимал в С-м (Столярном. - А.А.) переулке... и медленно...отправился к К-ну (Кокушкину. - А.А.) мосту» [5].

Этот же перекрёсток стал и местом действия незаконченной фантастической повести М.Ю. Лермонтова «Штосс». Главный герой её жалуется, что «... кто-то мне твердит на ухо с утра до вечера - и как вы думаете - что? - адрес: вот и теперь слышу: «В Столярном переулке, у Кокушкина моста, дом титюлярного советника Штосса, квартира номер двадцать семь» [6].

Лермонтов и сам жил недалеко от этого места - на Садовой улице, где он снимал квартиру для своей бабушки, но жил 
сам некоторое время. Здесь он узнал о смерти А.С.Пушкина и здесь написал «На смерть поэта».

Именно здесь, на пересечении Столярного переулка с набережной канала стоял и знаменитый в своё время огромный (по тем временам) доходный дом И.Д. Зверкова (№ 18) (рис. 10, 11), где на верхнем этаже в 1829-1833 годах жил начинающий писатель Гоголь-Яновский [7], которому старался помогать, подсказывая сюжеты, великий Пушкин и похоже посещал его в этом районе Мещанских улиц. Хозяин дома Зверков был ростовщиком и кредитором Пушкина по делам его отца [8, с 477]. Это место хорошо знал великий поэт и не случайно в 1829 году А. С. Пушкин упомянул Кокушкин мост (рис. 12) в известной эпиграмме на рисунок А. В. Нотбека «Пушкин и Онегин» [8, с. 37]:

Вот перешед чрез мост Кокушкин,

Опершись ж.... о гранит,

Сам Александр Сергеич Пушкин

С мосье Онегиным стоит.

Не удостоивая взглядом

Твердыню власти роковой,

Он к крепости стал гордо задом:

Не плюй в колодец, милый мой.

Именно этот перекрёсток становится все более современным: здесь, прямо на Кокушкином мосту, разворачиваются мерседесы и тойоты, не задумываясь, что где-то над ними жил двести лет назад автор «Мертвых душ» и «Ревизора»...

По другую сторону квартала - на перекрёстке Казначейской улицы с набережной канала до сих пор стоит доходный дом А.А. Астафьевой (1/61), построенный в 1826 году, возможно, по проекту архитектора К. Скотти, перестроенный в 1847 году архитектором И.И. Цимом, старейший из домов на бывшей Малой Мещанской улице - дом № 1 (№ 61 по каналу Грибоедова) (рис. 13). Это дом, где Ф.М. Достоевский вместе с своим братом Михаилом в принадлежащей брату квартире издавал в 1861-1867 годах журнал «Время». А после его закрытия - журнал «Эпоха» [2]. С 1861 по 1865 сам Фёдор Михайлович тоже снимал в этом доме квартиру из пяти комнат с кухнею, и в ней он закончил писать «Записки из мёртвого дома». Теперь в этом доме, покрашенном ныне в странный, отвратительный для города розовый цвет, открыта гостиница «Дом Достоевского».

Ну а напротив - в доме № 2 по Казначейской улице (рис. 14) тоже на втором этаже в квартире № 13 родился и прожил 15 лет автор этой статьи [9], который озаботился возможной потерей таких тихих и провинциальных перекрёстков возле самого центра бывшей столицы. Это позволило мне написать в книжке «Ближний мир» главу под названием «Мой сосед Фёдор Михайлович».

Это целая градостроительная структура невзрачных на первый взгляд, но овеянных славой русской литерату- ры перекрёстков вокруг главного креста - пересечения Столярного переулка с Казначейской улицей, далее - с Гражданской улицей, трёх Т-образных перекрёстков: двух с каналом и третий с Казанской улицей, и наконец - самый

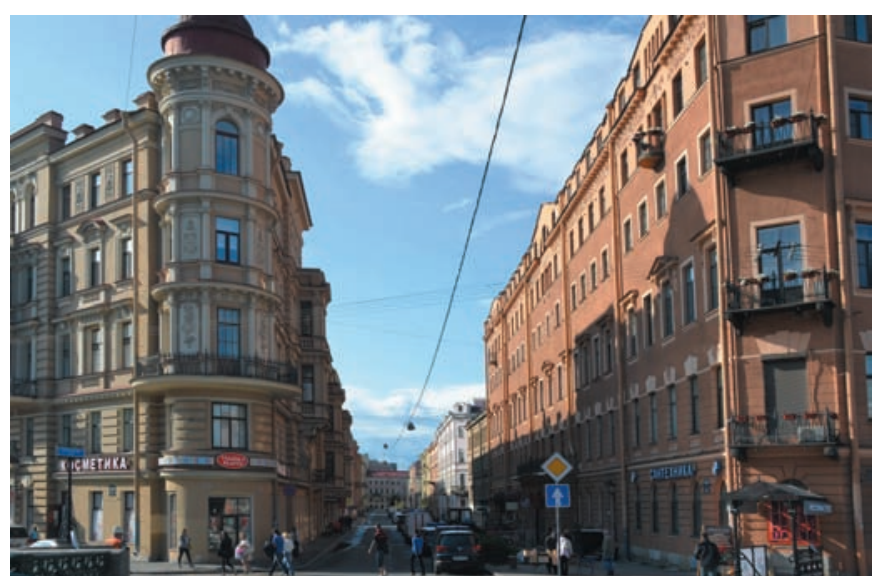

Puс. 10. Столярный переулка у Кокушкина моста. Справа дом, где жил Н.В. Гоголь, слева доходный дом Ратькова-Рожнова, который вобрал в себя немецкий трактир. Фото из открытых источников интернета

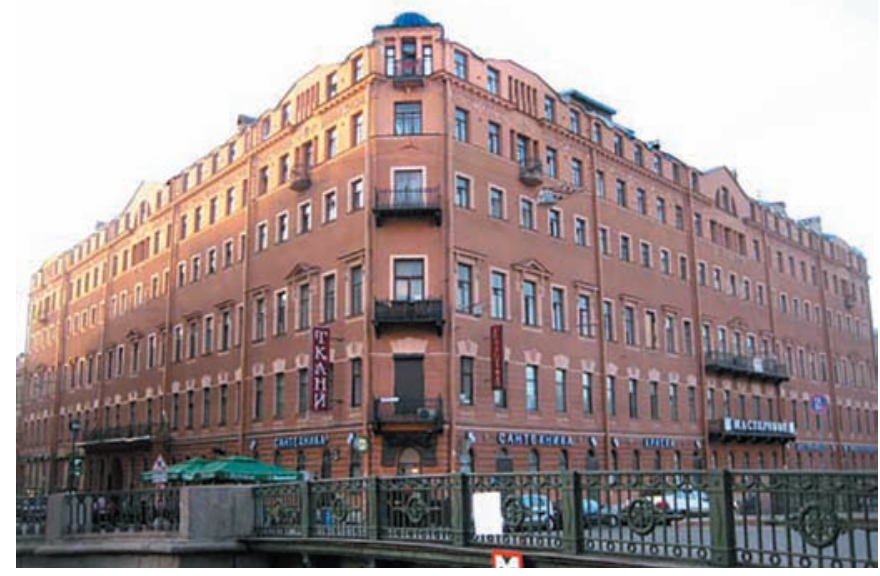

Puс. 11. Столярный переулок, 18/69. Доходнйй дом И.Д.Зверкова, где на верхнем этаже в квартире окнами на двор в 1829-1833 годах жил начинающий писатель Н.В. Яновский-Гоголь. Фото из открытых источников интернета

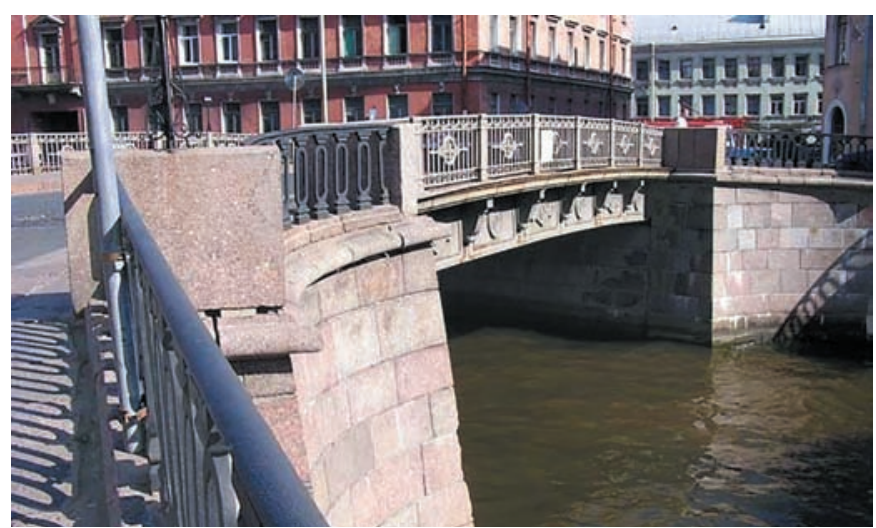

Рис. 12. Кокушкин мост. Фото из открытых источников интернета 


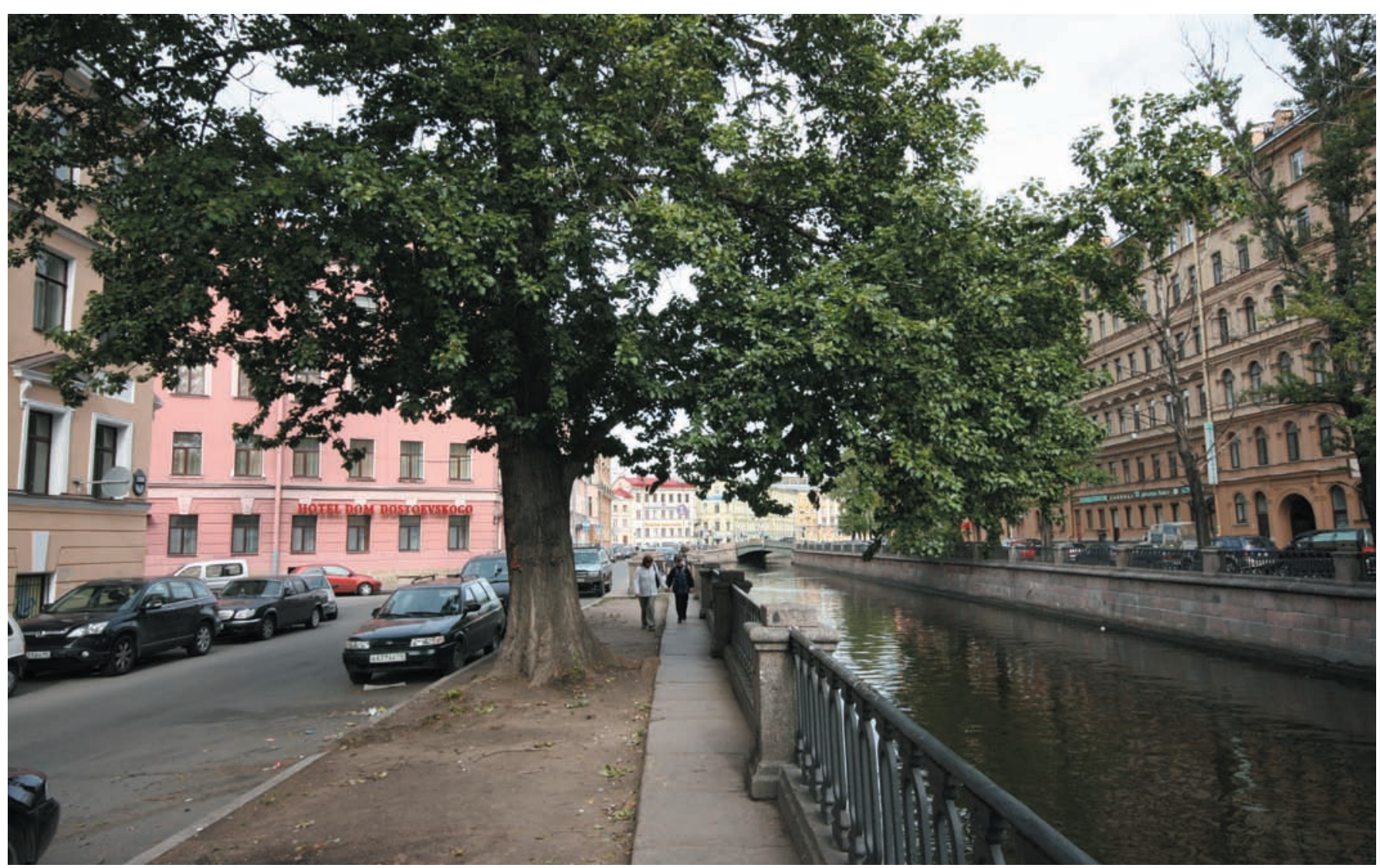

Рис. 14. Казначейская улица, 1/61. Доходный дом А.А. Астафьевой. С 1861 по 1863 Ф.М. Достоевский снимал здесь 5-комнатную квартиру. Сейчас в нём находится гостиница «Дом Достоевского». Фото А.В. Анисимова

тревожный - перекрёсток с разворотами современных автомобилей на Кокушкином мосту. Знали бы об этом Гоголь или Пушкин, наверное купили бы себе по «мерседесу» последней марки...

Итак, шесть скромных городских перекрёстков - четыре со Столярным переулком и два по концам Казначейской (бывшей Малой Мещанской) улицы, связаны с великими именами нашей литературы. Градостроительный оазис русской литературы, где бывали и писали Гоголь и Достоевский, Пушкин

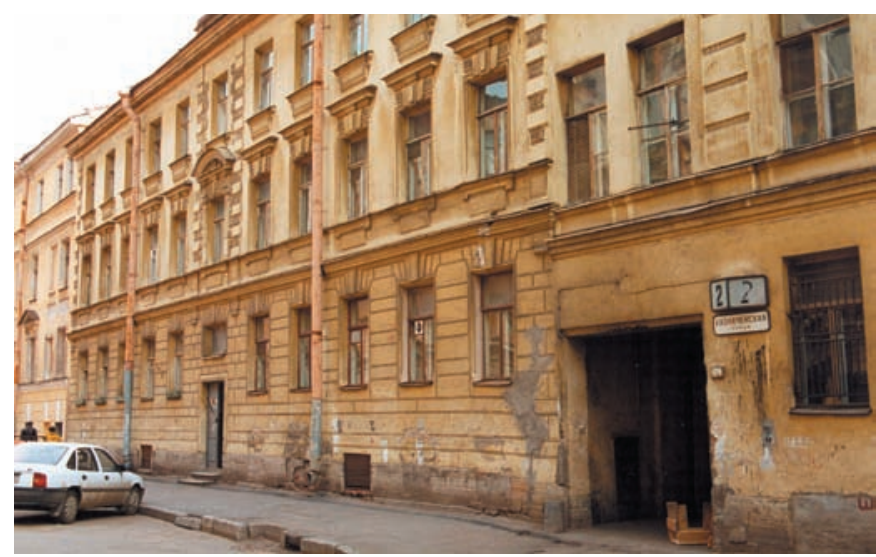

Рис. 15. Казначейская улица, 2 (напротив дома Достоевского), где жил я и выглядывал из окна, чтобы увидеть литературные места. Фото А.В. Анисимова и Лермонтов, Крылов и Шевченко, Тургенев, Глеб Успенский, Пржевальский и еще кто-то, кого мы позабыли или не знали.

Рядом - по другую сторону канала за горбатым Сенным мостом - изуродованная Сенная площадь, в прошлом идеологический центр прилегающего района с Сенным рынком и «Вяземской лаврой». Именно здесь в романе «Преступление и наказание» Раскольников «стал на колени среди площади, поклонился до земли и поцеловал эту грязную землю, с наслаждением и счастием. Он встал и поклонился в другой раз. - Ишь нахлестался! - заметил подле него один парень...

- Это он в Иерусалим идёт, братцы, с детьми, с родиной прощается, всему миру поклоняется, столичный город СанктПетербург и его грунт лобызает...» [5, с. 450].

Так город во многих произведениях становится незабываемым героем нашей литературы. А великая литература - охранной грамотой великого города и его тихих переулков возле незабываемого канала.

Чугунная ограда канала Грибоедова - символ этих мест.

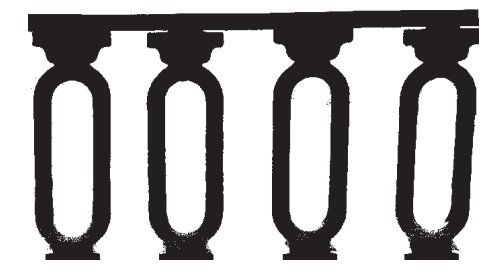




\section{Лuтература}

1. Анциферов Н.П. Петербург Достоевского / Н.П. Анциферов. - С-Пб : Изд.-во Брокгауз-Ефрон,1923.

2. История и дома Казначейской улицы [Электронный ресурс] // www.ilovepetersburg.ru. - Режим доступа: http://www.ilovepetersburg.ru/content/istoriya-i-domakaznacheiskoi-ulitsy (дата обращения 10.03.2020).

3. Анисимов А.В. Город Санкт-Петербург / А.В. Анисимов. - М. : Доброе слово, 2012.

4. Доходный дом Ратькова-Рожнова [Электронный ресурс]. - Режим доступа: www.citywalls.ru/house1137.html (дата обращения 04.03.2020).

5. Достоевский Ф.М. Преступление и наказание / Ф.М, Достоевский. - М. : Правда, 1987.

6. Лермонтов М.Ю. Штосс [Электронный ресурс] / М.Ю. Лермонтов // Интернет-библиотека Алексея Комарова. Режим доступа: https://ilibrary.ru/text/1150/p.1/index.html (дата обращения 01.02.2020).

7. Воропаев B.A. Гоголевский Петербург [Электронный ресурс] / В.А. Воропаев // Петербург реальный и литературный. - Режим доступа: https://www.sites.google.com/site/ litpeterburg/peterburg-gogola (дата обращения 10.02.2020).

8. Зуев Г.И. Вдоль канала Грибоедова / Г.И. Зуев. - М.-СПб : Центрополиграф. МиМ-Дельта, 2006.

9. Анисимов А.В. Ближний мир / А.В. Анисимов. - М., 2008.
References

1. Antsiferov N.P. Peterburg Dostoevskogo [Petersburg Dostoevsky]. Saint Petersburg, Publishing House of BrockhausEfron, 1923.

2. Istoriya i doma Kaznacheiskoi ulitsy [History and houses of Treasury Street]. www.ilovepetersburg.ru. Access mode: http://www.ilovepetersburg.ru/content/istoriya-i-domakaznacheiskoi-ulitsy (Accessed 10.03.2020).

3. Anisimov A.V. Gorod Sankt-Peterburg [City St. Petersburg]. Moscow, Dobroe slovo Publ., 2012.

4. Dokhodnyi dom Rat'kova-Rozhnova [Apartment building Ratkova-Rozhnova]. Access mode: www.citywalls.ru/house1137. html (Accessed 04.03.2020)

5. Dostoevskii F.M. Prestuplenie i nakazanie [Crime and Punishment]. Moscow, Pravda Publ., 1987.

6. Lermontov M.Yu. Shtoss. Internet-biblioteka Alekseya Komarova [Internet library of Alexei Komarov]. Access mode: https://ilibrary.ru/text/1150/p.1/index.html (Accessed 01.02.2020).

7. Voropaev V.A. Gogolevskii Peterburg [Gogol Petersburg]. Peterburg real'nyi iliteraturnyi [Petersburg real andliterary]. Access mode: https://www.sites.google.com/site/litpeterburg/ peterburg-gogola (Accessed 10.02.2020).

8.Zuev G.I. Vdol' kanala Griboedova [Along the Griboedov Canal]. Moscow-Saint Petersburg, Tsentropoligraf. MiM-Del'ta Publ., 2006.

9. Anisimov A.V. Blizhnii mir [The Near World]. Moscow, 2008.

Анисимов Александр Викторович (Москва). Доктор архитектуры, член-корреспондент РААСН, академик МААМ. Профессор ВГИК и МГСУ, главный научный сотрудник филиала ФГБУ «ЦНИИП Минстроя России» Научно-исследовательского института теории и истории архитектуры и градостроительства (111024, Москва, ул. Душинская, 9. НИИТИАГ). E-mail: alexandranisimo@ yandex.ru; anisimov1935@gmail.com.

Anisimov Alexander V. (Moscow). Doctor of Architecture, Corresponding Member of RAACS, Academician of IAAM. Professor of VGIK and MGSU, Chief Scientific Officer of the Research Institute of Theory and History of Architecture and Urban Planning (9 Dushinskaya st., Moscow, 111024. NIITIAG), branch of the Central Institute for Research and Design of the Ministry of Construction and Housing and Communal Services of the Russian Federation (TsNIIP). E-mail: alexandranisimo@yandex.ru; anisimov1935@gmail.com. 